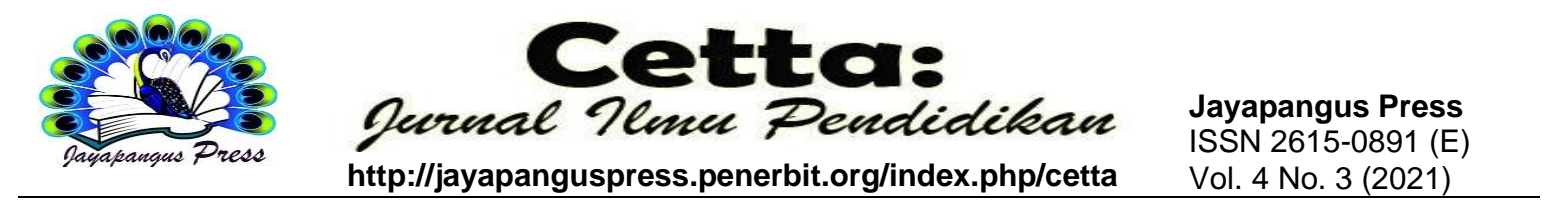

\title{
STEAM or not STEAM: Delving into Teacher's Planning in Early Child Bilingual Education
}

\author{
Ni Putu Wismayani Pratiwi ${ }^{1}$, Made Hery Santosa ${ }^{2}$ \\ ${ }^{12}$ Universitas Pendidikan Ganesha \\ ${ }^{1}$ pratiwi.wismayani@gmail.com, ${ }^{2}$ mhsantosa@undiksha.ac.id
}

\begin{tabular}{l}
\hline Keywords: \\
\hline STEAM; Early \\
Childhood \\
Education; \\
Creativity; \\
Critical Thinking \\
\hline
\end{tabular}

\begin{abstract}
This study aims at analyzing the extent to which the weekly planning by playgroup teacher in a bilingual early childhood education reflects on STEAM. This was qualitative research that involved a female playgroup teacher who teaches in a bilingual early childhood education in Denpasar, Bali. Meanwhile, the object of this research was 39 weekly plans with 15 themes in the academic year of 2020/2021. There were two methods of data collection used in this study, such methods as document analysis and interview. The instruments used were analysis form checklist and interview guide The weekly plans were analyzed by the document analysis method to determine the extent to which STEAM was reflected in the weekly plan. Meanwhile, a one-onone interview was conducted to obtain data on teacher knowledge about STEAM. The results of this study found that all of the weekly plans reflected on STEAM. Even though each aspect STEAM was not evenly distributed since the goal of the school focuses on pre-literacy and pre-numeracy. Therefore, Science and Math were mostly appeared in the teacher's planning. Furthermore, it was obtained from the interview that the teacher had a good comprehension about STEAM and its implementation. This study gives an insight to the other playgroup teachers about how to integrate STEAM in their planning. However, this research was conducted on a small scale and without classroom observations. Further research is expected to be carried out on a large scale and by observing the class.
\end{abstract}

Kata Kunci:

STEAM;

Pendidikan Anak

Usia Dini;

Kreativitas;

Berpikir Kritis

\begin{tabular}{l} 
Abstrak \\
\hline Penelitian ini bertujuan untuk menganalisis sejauh mana \\
perencanaan mingguan oleh guru playgroup di PAUD bilingual \\
mencerminkan STEAM. Penelitian ini merupakan penelitian \\
kualitatif yang melibatkan seorang guru playgroup perempuan \\
yang mengajar di PAUD bilingual di Denpasar, Bali. \\
Sedangkan objek penelitian ini adalah 39 rencana mingguan \\
dengan 15 tema pada tahun ajaran 2020/2021. Ada dua metode \\
pengumpulan data yang digunakan dalam penelitian ini, yaitu \\
\hline
\end{tabular}


metode analisis dokumen dan wawancara. Instrumen yang digunakan adalah checklist formulir analisis dan pedoman wawancara. Rencana mingguan dianalisis dengan metode analisis dokumen untuk mengetahui sejauh mana STEAM tercermin dalam rencana mingguan. Sedangkan wawancara satu lawan satu dilakukan untuk mendapatkan data pengetahuan guru tentang STEAM. Hasil penelitian ini menemukan bahwa semua rencana mingguan tercermin pada STEAM. Meskipun setiap aspek STEAM tidak merata karena tujuan sekolah berfokus pada pra-literasi dan pra-berhitung. Oleh karena itu, IPA dan Matematika lebih banyak muncul dalam perencanaan guru. Selanjutnya diperoleh dari wawancara bahwa guru memiliki pemahaman yang baik tentang STEAM dan implementasinya. Studi ini memberikan wawasan kepada guru kelompok bermain lainnya tentang bagaimana mengintegrasikan STEAM dalam perencanaan mereka. Namun, penelitian ini dilakukan dalam skala kecil dan tanpa observasi kelas. Penelitian selanjutnya diharapkan dapat dilakukan dalam skala besar dan dengan observasi kelas.

\section{Introduction}

Early Childhood Education is an important education for students to become the basic foundation for further cognitive, psychomotor and affective development (Gomez, 2016). Early Childhood Education aims to prepare students to be ready to enter primary school education (Taguma et al., 2012). For this reason, the teachers must be able to understand the characteristics of each child so that the stimulation and guidance given to students is right on target. Therefore, early childhood education's teachers must always be up-to-date in finding the learning approach, method, and strategy that are suitable for his/her students. The factor that might influences the learning approach, method, and strategy used to teach in early childhood education are the skills needed in recent education situation

In the 21st century, education is identified by four main skills that must be possessed, namely: creativity, critical thinking, communication, collaboration (Artini \& Padmadewi, 2019; Erdoğan, 2019). Collaboration is meant as the ability to work together with peers or colleague (Artini \& Padmadewi, 2019). Meanwhile, creativity is the ability to think and act out of the box which can create something new (Artini \& Padmadewi, 2019). Furthermore, critical thinking is said as the ability to judge, evaluate and solve problems in the real context as effective as possible and communicative is the ability to express ideas and communicate with the others effectively (Artini \& Padmadewi, 2019). Therefore, the skills are important given to early childhood education. 
Related to recent situation, the COVID-19 pandemic has brought major changes in early childhood education in Indonesia. The physical distancing policy set by the government has the consequence that almost all students in Indonesia, from early childhood to university students, cannot conduct face-to-face learning activities at school. The learning process has to be carried out remotely from their home or known as distance learning. It is where the students do online learning at home and they communicate with their teacher through applications like chat, video call, LMS, etc. (Kimkong \& Koemhong, 2020)

To support the distance learning for early childhood education, a child-friendly learning approach is needed. The approach must be home friendly and easily implemented by parents and teachers. One of learning approaches that supports this distance learning is STEAM (Science, Technology, Engineering, Art, and Math). This learning approach was developed to facilitate $21^{\text {st }}$ century education in which the students are expected to have the 4C's skills. In STEAM, students are encouraged to develop their curiosity and ask questions related to their interest (Martinez, 2017). STEAM also leads the students to build knowledge by exploring, observing, discovering and investigating how things work (Martinez, 2017). This learning approach can be done by studying something that happens every day and by using materials available around the student.

In the initial year, the term STEM was first launched by the US National Science Foundation in the 1990s under the name SMET. However, the term was not approved by several parties so that SMET was changed to STEM as the theme of the education reform movement in the four disciplines of increasing global competitiveness of the United States (US) in science and technology innovation. STEM is an acronym for Science, Technology, Engineering, and Mathematics. Torlakson (2014) argues that STEM is appropriate to coordinate science and real problems that occur in the real world. It is because STEM includes critical thinking, analysis, and collaboration processes where students integrate processes and concepts in real-world contexts from science, technology, engineering, and mathematics to encourage the development of skills and competencies for college, career, and life. Furthermore, Pfeiffer et al. (2013) stated that in STEM learning, skills and knowledge are learned simultaneously by students.

STEAM (Science, Technology, Engineering, Art and Mathematics) is an approach that combines the five disciplines (Science, Technology, Engineering, Arts and Mathematics). Science refers to knowledge that is acquired through observation, study, 
and experiment (Martinez, 2017). It is a process for students to understand and also find out about various things by becoming an investigator (Awang et al., 2020). It can make students more sensitive and critical thinking because they use their sense to do all the activities (Awang et al., 2020; Martinez, 2017). Technology in early childhood education is any tool created by human like scissor, pencil color, crayons, etc. (Awang et al., 2020). These tools are introduced from an early age so that students can use and also develop what they use. Engineering can be interpreted as the way to solve a problem based on one's creativity (Awang et al., 2020). This includes the way on how to use tools or technology to solve certain problem. Arts is one of exploration activities that is able to activate the student's creativity. It include drawing, painting, sculpture, architecture, music, literature, drama, and dance. Art is done to train students to experiment with their imagination. The last part is math which consists of the activities involving the students to identify and classify (Perignat \& Katz-Buonincontro, 2019). In the early childhood context, when the students are able to say comparative words such as: bigger, thicker, and smaller, it means that they have used the concept of math.

STEAM is integrated in Early Childhood Education learning with some aspects that need to be considered. These aspects consist of (Putri, 2019 in Harjanty \& Hardianti, 2020); 1. Questioning is about asking questions about objects or events that were happened around them; 2. Exploring and observing is an active exploration activities through observation using all senses; 3.Developing skills and processes can be in the form of building, creating and designing using various materials and techniques such as numbers, measurements and making shapes, identifying and trying to enable solutions to problems, collecting, comparing, sorting, classifying, interpreting, describing observations; 4. Communication is about developing various language skills and communicating with others, working individually or in groups and sharing and discussing ideas through conversing, listening and writing; 5. Playing: learning takes place by applying the principles of play. It applies knowledge and skills simultaneously to solve a problem, stimulate curiosity and motivation students about high-level skills that include problem solving, collaboration, project-based learning, challenge-based learning and research (Martinez, 2017). It is used to focus on understanding the integrated nature of the disciplines of science, technology, engineering, arts, and mathematics and their importance in students' long-term academic success, economic well-being (Quigley \& Herro, 2016). 
Due to the outbreak of COVID 19, the present study aims at analyzing the extent to which the weekly planning by playgroup teacher in a bilingual early childhood education reflects on STEAM. The research question can be formulated as: "How does the weekly planning by playgroup teacher in a bilingual early childhood education reflect STEAM?" Hence, this study is aimed to know how the weekly planning by playgroup teacher in a bilingual early childhood education reflects STEAM. This study is important to be conducted for verifying the weekly planning made by playgroup teacher in a bilingual early childhood education integrating the STEAM.

\section{Method}

This study was a qualitative study. According to Gay et al. (2012), qualitative research is the collection, analysis, and interpretation of comprehensive non-numerical data to gain insights into a particular phenomenon of interest. The data were presented descriptively. It was chosen because it suited the aim of study, which was know how the weekly planning by playgroup teacher in a bilingual early childhood education reflects STEAM. Hence, the weekly planning in academic year of 2020/2021 constructed by a teacher were analyzed in order to know the activities which reflect STEAM. In addition, the interview was conducted for its validity. This study was conducted at an early childhood bilingual education in Denpasar.

This school used both National and Cambridge curriculum. Meanwhile, the teacher interviewed was a female and an Indonesian majoring a bachelor of early childhood. She annually attended training for early childhood education conducted by the education department or training centre. Based on the pre-interview, the teacher was assumed to know about STEAM and she was familiar in integrating STEAM in their planning. However, there was uncertainty about the integration of STEAM in the weekly planning. There were two methods of data collection used in this study, such methods as document analysis and interview. The instruments used were analysis form checklist and interview guide. In this research, the documents were in the form of weekly planning made by playgroup teacher. There were 39 weekly plans with 15 themes. The documents were analyzed by correlating the learning activities with the five aspects of STEAM. The oneon-one interview was conducted in order to get the teachers share their idea freely in the setting they chose (Creswell, 2009). It was conducted to a female playgroup teacher related to her knowledge of STEAM and STEAM in her weekly planning through WhatsApp. It was conducted afterward the document analysis. 


\section{Result and Discussion}

STEAM stands for Science, Technology, Engineering, Arts, and Mathematics which includes scientific technology-based learning and the ability to solve problems in the real world (Martinez, 2017; Thuneberg et al., 2018). Science requires students to be able to use the scientific method approach in solving a problem in everyday life. In technology aspect, students must be familiar with the use of tools in their daily life. Engineering leads the students demonstrate the way to use tools or technology to create a product or can also look for appropriate solutions. While arts lead the students to create their products using their imagination and creativity. The last is in Mathematics that guides students to use a mathematical approach in processing the data they get. The following paragraphs are the result of document analysis.

Term 1

Term 1 consisted of 8 weeks with 3 themes namely me and myself, I take care of myself, and fun at playground. In this term, the science was mostly about introducing sounds phonic "s, a, t, i, p, n". Meanwhile, lacing, flying kite and construction building using Lego and 2D shapes were appeared in engineering. Art in this term was in form of singing phonics song, drawing, and role play. Math was mainly about recognizing number from 1-5, comparing the size of their body part, and recognizing $2 \mathrm{D}$ shapes. The tools used were wooden block, Lego, scissor, crayon, pencil color, string, ribbon, needle, origami paper, glue, and marker.

Term 2

There were 10 weeks in the second term with 4 themes namely my favorite toys, flowers in our garden, nursery rhymes, and Christmas celebration. In this term, the activities were mainly designed where the students were encouraged to be a little investigator to find the objects with certain initial sounds, to do experiment about sinking and floating, and plant the seed under the light and in the dark place. The natural objects such as leaves, stem, the root of plants and rocks were included as the tools of learning. Meanwhile, the team building and construction appeared as the representation of Engineering. Furthermore, making bubbles from hibiscus leaves was one of the experiment appeared in this term. The Art in the STEAM was represented through singing, finger painting, cotton painting, and role-playing from traditional games such as meong-meong. Math appeared in the form of counting, ordering, and filling the missing 
number. Besides, comparing the tall and short object, differentiating less and more were also the part of math

Term 3

Term 3 had 9 weeks that consisted of 4 themes. They were My Pets, On the Farm, At The Zoo, and Nyepi Celebration. Science was generally depicted in the activities such as shared reading and find out the moral value, reviewing the sounds phonics in level 1 and 2, and recognizing the letters in the student's name. Moreover, the experiment of mixing color using food coloring was emerged in this term. Meanwhile, the technology used was similar to technology in the term 1 such as scissor, crayon, pencil color, stick, origami, and ribbon. The engineering in term 3 was usually wrapped up in the art such making craft and playing with play dough to make an egg. The most common activity was making animal puppets and continued with role-play using the puppets. Besides, painting using recycled tissue rolled tube was found as art. Math was focused on counting and ordering the numbers.

Term 4

There were 11 weeks in the term 4. It had 4 themes namely Under the Sea, I Love My Earth, Day and Night, and End of School Year Party. In the term, the focus of science was reviewing all the phonics both in English and Indonesian. Question and answer after shared reading was also appeared. Besides, there was an experiment to make volcano explosion in this the theme I Love My Earth. Making the earth using play dough was appeared in this term. It represented the engineering and art at once. Meanwhile, for math, counting, sequencing, and ordering numbers from 1 to 10 were still the focus.

The results of this study indicate that learning activities in weekly planning had reflected STEAM. Even though each aspect was mainly appeared with the similar activities in term by term, but all of the weekly plans had reflected STEAM. Science, Art and Math were the dominant aspects of STEAM appeared in the weekly plans. There were several sciences activities planned by the teacher in weekly plan such as question and answer on certain topic that can attract students' interest, reviewing sound phonics both in Indonesia and English, and doing experiment. Then, in the aspect of technology, stationaries were the tools that were often used to support learning activities such as scissors, pencil colors, crayons, and loose parts from plastic, natural materials, recycled cardboard, as well as strings and ribbon. Then, the activities that were designed for engineering such as how to wash hands properly and how to plant trees. Furthermore, in 
the arts, activities are not only designed for singing and dancing, but also role playing and playing traditional games. In math, number recognition activities through counting, sequencing, and ordering were also often seen in the teacher's weekly plans. Here is the example of weekly plan:

Table 1. Weekly plan of Flowers in Our Garden-themed

$$
\text { PLAYGROUP ACTIVITIES }
$$

Monday, 2nd November 2020 - Friday, 6th November 2020

\begin{tabular}{|c|c|c|c|c|}
\hline Monday & Tuesday & Wednesday & Thursday & Friday \\
\hline $\begin{array}{l}\text { 1. Hands-on } \\
\text { activity: } \\
\text { a. count and } \\
\text { take } \\
\text { objects } \\
\text { b. trace } \\
\text { number } 5 \\
\text { worksheet } \\
\text { c. practice } \\
\text { to write } \\
\text { number } \\
\text { formation } \\
\text { on board } \\
\text { or paper } \\
\text { 2. Observing } \\
\text { what kind of } \\
\text { plants do the } \\
\text { students see } \\
\text { in the garden } \\
\text { 3. Draw what } \\
\text { they see in } \\
\text { the garden } \\
\text { 4. Reordering } \\
\text { number } \\
\text { puzzle (cut } \\
\text { and paste } \\
\text { activity) }\end{array}$ & $\begin{array}{l}\text { 1. Reviewing } \\
\text { all sounds } \\
\text { introduced } \\
\text { (s,a,t,i,p,n,c) } \\
\text { 2. Sing the } \\
\text { song of jolly } \\
\text { phonics } \\
\text { 3. Recognizing } \\
\text { the initial } \\
\text { sound of } \\
\text { some words } \\
\text { 4. Find the } \\
\text { same letter } \\
\text { worksheet } \\
\text { 5. Colour the } \\
\text { tree with } \\
\text { paint (finger } \\
\text { painting } \\
\text { activity) } \\
\text { 6. Cut and } \\
\text { paste - } \\
\text { flower in the } \\
\text { pot }\end{array}$ & $\begin{array}{l}\text { 1. Shared } \\
\text { reading } \\
\text { "Kenapa } \\
\text { Bungaku? } \\
\text { 2. Investigate } \\
\text { parts of } \\
\text { plants in the } \\
\text { garden } \\
\text { 3. Reviewing } \\
\text { "r" and "m" } \\
\text { Indonesian } \\
\text { Sounds } \\
\text { 4. Game } \\
\text { "jump on } \\
\text { the sound!" }\end{array}$ & $\begin{array}{l}\text { 1.Reviewing “ } \\
\text { m” in } \\
\text { Indonesian } \\
\text { Phonic } \\
\text { through } \\
\text { song and } \\
\text { movement } \\
\text { 2.Tracing the } \\
\text { "m" } \\
\text { 3.Sorting 2D } \\
\text { shapes } \\
\text { 4.Count the } \\
\text { Triangles, } \\
\text { circles, and } \\
\text { squares } \\
\text { 5.Draw } \\
\text { simple } \\
\text { picture } \\
\text { (flower) }\end{array}$ & $\begin{array}{l}\text { 1. Class } \\
\text { project } \\
\text { (collage on } \\
\text { the petal - } \\
\text { paper } \\
\text { crumpling) } \\
\text { 2. Reviewing } \\
\text { "s, a, t, i, p, } \\
\text { n, c, k, e, h, } \\
\text { r, m" } \\
\text { through } \\
\text { fishing } \\
\text { game } \\
\text { 3. Count the } \\
\text { frangipani } \\
\text { petals } \\
\text { 4. Singing } \\
\text { "Lihat } \\
\text { Kebunku" }\end{array}$ \\
\hline
\end{tabular}

On Monday, $2^{\text {nd }}$ November 2020

The activities had reflected on STEAM. Observing the plants in the garden of school reflected on Science. Then, the students were asked to draw plants that they saw in the garden. In drawing, the students needed to use their visual knowledge about plants and they needed to know how to use pencil. This activity had integrated Technology, Engineering, and Arts. Math also appeared when the students were asked count and take the object, tracing number 5 and write the number formation.

On Tuesday, $3^{\text {rd }}$ November 2020 
STEAM can be seen in the activities on Tuesday. Reviewing all the sound introduced, recognizing the initial sound of some words and finding the same letter on worksheet belonged to Science. Meanwhile, singing jolly phonics was the integration of science and arts. Finger painting and cut and paste flower activity were the reflection of STEAM. The students needed to observe the part of plant and the color of each part before they pasted or painted it. This was science. To cut the part of plant or to paint it, the students needed scissor and paint as the technology. Engineering appeared when the students do cutting practice or painted the plant. Then, arts was also needed to put right color on their painting. Ordering the part of plant before pasting those in correct order need mathematic approach.

On Wednesday, $4^{\text {th }}$ November 2020

Art in the form of literature could be seen in the shared reading activity. It also appeared science when the teacher do question and answer with the students related to the book being read. Besides, reviewing the phonics and investigating the part of plant could be the part of science. Then, game "jump on the sound!" might consist of science and math since the students need to recognize the sound and match it with its shape.

On Thursday, $5^{\text {th }}$ November 2020

Science and Art could be seen in the reviewing Indonesian Phonic through song and movement. They need to observe the shape of letter while singing and dancing. How to trace and how to draw were categorized as engineering using pencil or crayon which belonged to technology. Then, math and science came up in the sorting and counting the 2D shapes.

On Friday, $6^{\text {th }}$ November 2020

Reviewing "s, a, t, i, p, n, c, k, e, h, r, m" through fishing game could represent science, technology, and engineering as the students had to recognize and match the sound and its shape, know how to use the fishing rod to take the sound letter. Count the frangipani petals was kind of math activity. Meanwhile, the class project required the students to crumple the paper to make a flower in the big paper. It took out the all the disciplines in STEAM. Art was appeared through singing "Lihat Kebunku”.

It was clear enough that the learning activities designed by teacher in weekly plan reflecting STEAM. This is in line with the results of interviews with teachers who made the weekly plan. The teacher said that STEAM had been implicitly integrated into lesson planning. She stated that: 
Science refers to basic concepts that can be applied by conducting questions and answers to students. Then, Technology refers to the tools used for learning activities. Engineering is a way of using tools for learning. So technology and engineering are related. As for art, it relates to art which can be in the form of singing, dancing, and handicraft activities. While mathematics is clear it refers to numbers, comparisons, and shapes.

From these results, it can be indicated that the teacher had understood the concept of STEAM well and integrated STEAM in the learning activities she designed. Furthermore, she said that art and math were the dominant aspects because the school set a goal to introduce students to pre-literacy and pre-numeracy skills.

With respect to the findings, integrated STEAM in learning activities for students aged 3 to 4 years supports the development of student creativity, or as a means to improve problem solving skills in daily activities (Perignat \& Katz-Buonincontro, 2019). STEAM can increase students' creativity because students are taught to learn to process in the form of observing, playing, recognizing patterns and practicing creative thinking skills as well as collaboration and communication skills between other students in completing a task given by the teacher as facilitators (Guyotte et al., 2014). In other words, the students are taught the process of scientific approach. The scientific approach let the children to develop their thinking way through observing, asking questions, gathering information, reasoning, and communicating (Yennizar et al., 2020). All of the student's senses is used as well as various sources and learning media. So it also trains the student's fine motor and eye coordination (Yennizar et al., 2020). This approach is inserted in playing activities, as well as other activities, such as role playing, literacy or artistic activities (Yennizar et al., 2020). In the example of planning, it was written that students were asked to observe the plants around them. Observing is one of elements in scientific approach. Then, the students were also required to collect the information about the part of plants they found.

Introducing STEAM to early years students prepare them for the 21st Century challenges (DeJarnette, 2018). STEAM activities provide preschoolers with a natural environment for collaboration and communication (DeJarnette, 2018). STEAM trains the student to be more critical as they have to solve problems in the real world (Martinez, 2017). The students are also trained to dare to express themselves in the form of criticism and opinions when STEAM is integrated in their learning activities. From this point of view, it improves students' verbal and non-verbal communication skills (Awang et al., 2020). Moreover, STEAM develops students' potential to make connections between 
learning materials, learning designs and the surrounding environment (Sochacka et al., 2016) . In addition, they are also encouraged to solve problems with their teachers and peers (Michaud, 2014). In other word, collaboration skill is trained through STEAM. In can be inferred that STEAM also encourages the students to have 4C's skills. Moreover, phonics and numbers were mostly found in the teacher's planning. It was the basic skills to develop the student's literacy and numeracy skills. Teaching the initial STEAM allows the children to acquire and use these basic skills appropriately, in meaningful contexts that are relevant to their daily lives (Soylu, 2016 in Harjanty \& Hardianti, 2020).

Science in early childhood can be interpreted as the approach that stimulates children to increase their curiosity, interest and problem solving. It is focused on learning about the children itself, their environment and its phenomena (Munawar et al., 2019). Preschool children are the natural scientists who use their sense of creativity, curiosity, and persistence to explore, create, and innovate (Banko et al., 2013 in DeJarnette, 2018). They are enthusiastic to acquire basic knowledge and understanding of how the world works (Koester, 2013 in DeJarnette, 2018). Thus, the preschoolers are the ones in a great age to introduce science literacy (Koester, 2013 in DeJarnette, 2018). Regarding to this statement, the themes in the teacher's weekly planning had been included the three main focuses that should be in such as me and myself, my pets, and I love my earth. Furthermore, Wahyuningsih et al. (2020) argued that there are some benefits of learning science in early childhood such as: a) learn to explore and investigate objects and natural phenomena; b) learn to develop basic science process skills, such as making observations, measuring, communicating the results of observations, etc.; c) learn to develop curiosity, pleasure and willingness to make inquiries or discoveries; d) learn to understand the knowledge of various objects both its characteristics, structures and functions. Some activities or science experiments appeared in the teacher's weekly planning include: a) volcanic explosion experiments; b) colour mixing; c) making bubble from hibiscus leaves; d) planting the seed in the light and dark place and e) sinking and floating.

In early childhood education, the term technology refers to use of equipment that can develop gross and fine motor skills (Munawar et al., 2019; Wahyuningsih et al., 2020). Equipment or tools can help children to develop hand-eye coordination, as well as train and strengthen hand and finger muscles for writing, typing and drawing (Munawar et al., 2019). Some activities that were found in teacher's weekly planning related to technology games for early childhood including playing with non-electronic technologies 
such as: scissors, string and needle, wooden blocks, lego, stationery, used tissue roll tubes, plastic straws, and natural objects such as leaves, steam and roots of the plants.

Engineering is the knowledge to operate or design a procedure to solve a problem (Awang et al., 2020; Munawar et al., 2019). In other words, it can be said that engineering is a skill that someone has to operate or assemble something. In early childhood engineering is taught explicitly which is integrated with technology (Wahyuningsih et al., 2020). The application of engineering in the early childhood education can be in the form of building tower from the blocks or demonstrate about how to use scissor (Mcclure et al., 2017; Wahyuningsih et al., 2020).. They are capable of discussing different strategies and suggestions for a simplistic engineering design (DeJarnette, 2018). In the teacher's weekly planning, it was found the activity that required the students to build their favorite toys from the Lego. In order to make their favorite toys, they have to decide which part of toys come first then put it in the correct order. It means that engineering train the students to identify a problem before solve that problem (Awang et al., 2020). When the students build something based on their creativity, it means that they experience a process to analyze, develop, and evaluate their designs (Wahyuningsih et al., 2020).

Furthermore, art in early childhood include recognizing and showing various artistic works and activities, such as drawing, painting with a brush, finger painting, stamping, folding (Awang et al., 2020; Wahyuningsih et al., 2020). Meanwhile, performing arts can be in the form of mini dramas, singing, telling stories, dancing, playing music and exploration with objects such as making play dough, making collages from various materials, and coloring (Munawar et al., 2019). This studies found that the teacher had attached both visual and performing art in the weekly planning. Art is really important for children in the early childhood education because it stimulate the development of children in cognitive, social, emotional and physical aspects (Doyle, 2017). In other words, art influences all areas development of children.

Math does not always relate to number in the early childhood education. It can be in the form of comparing size and color, sorting out objects, and pattern recognition (Munawar et al., 2019). Children are said to have higher order thinking skills when they can understand the concept that comparison is relative depending on the objects being compared (Perignat \& Katz-Buonincontro, 2019). To strengthen the concept of mathematics, it is better to embed mathematics as part of daily activities (Perignat \& KatzBuonincontro, 2019). In this study, the teacher had put the concept of math in the 
planning. Besides counting and ordering, the concept of math that was appeared was in the form of matching the numbers with the objects, comparing the size, and differentiating the concept of less and more.

The finding also showed that the teacher used loose parts made of plastic and natural materials. Loose-parts are items that are easily found in the environment around students, which can be used as learning media (Wahyuningsih et al., 2020). These looseparts items do not only support students' development, but also help students to connect themselves with their environment (Munawar et al., 2019; Wahyuningsih et al., 2020). It would be even better if the loose parts used came from natural materials such as stones, shells, twigs, dry leaves. When students use objects in nature, they can use them for anything according to their ideas. This will develop the student's imagination, creativity, language and knowledge. The development of creative thinking skills must begin since the child is in the kindergarten, where at this stage the child needs to be encouraged to imagine, create, and recognize various knowledge and practices. It is important for both parents and teachers to build students' perceptual, conceptual and analytical points of view from an early age, because at this stage they begin to build self-creativity that will affect their future (Yalcin, 2015).

\section{Conclusion}

From the weekly planning, STEAM has been integrated into the learning activities designed by the playgroup teacher at the bilingual school. STEAM activity in the teacher's weekly planning is seen to encourage playgroup students to develop the student's creativity and be more critical thinking. This is supported by the teacher's ability to understand the concept of STEAM. In addition, STEAM has a positive impact on early childhood in terms of creativity. STEAM leads students to become more capable in solving the problems they face. This study give an insight to the other playgroup teachers about how to integrate STEAM in their planning. However, this research was conducted on a small scale and without classroom observations. Further research is expected to be carried out on a large scale and by observing the class. 


\section{References}

Artini, L. P., \& Padmadewi, N. N. (2019). Cyclic Relective Model for Promoting Prospective English Teachers' Creativity in Instructional Designing. Advances in Social Science, Education and Humanities Research, 1-5.

Awang, Z., Yakob, N., Hamzah, A., \& Talling, M. M. (2020). Exploring STEAM Teaching in Preschool Using Fred Rogers Approach. International Journal of Evaluation and Research in Education, 9(4), 1071-1078. https://doi.org/10.11591/ijere.v9i4.20674

Creswell, J. W. (2009). Research Design Qualitative, Quantitative, and Mixed Methods Approaches. In Sage (Third Edit). Sage Publications, Inc. https://doi.org/10.2307/1523157

DeJarnette, N. K. (2018). Implementing STEAM in the Early Childhood Classroom. European Journal of STEM Education, 3(3), 1-9. https://doi.org/10.20897/ejsteme/3878

Doyle, M. (2017). Elements of Art. Steam, 3(1), 1-5. https://doi.org/10.5642/steam.20170301.17

Erdoğan, V. (2019). Integrating 4C Skills of 21st Century into 4 Language Skills in EFL Classes. International Journal of Education and Research, 7(11), 113-124.

Gay, L. .., Mills, G. E., \& Airasian, P. (2012). Educational Research: Competencies for Analysis and Applications. Pearson Education, Inc.

Gomez, R. (2016). Sustaining the Benefits of Early Childhood Education Experiences: A Research Overview. Voices in Urban Education, 43, 5-14. https://eric.ed.gov/?id=EJ1101330

Guyotte, K. W., Sochacka, N. W., Costantino, T. ., Walther, J., \& Kellam, N. N. (2014). STEAM as Social Practice: Cultivating Creativity in Transdisciplinary Spaces. Art Education, 67(6). https://doi.org/10.1080/00043125.2014.11519293

Harjanty, R., \& Hardianti, F. (2020). Analysis of The Application of STEAM-Based Learning. Indonesian Journal of Early Childhood, 9(2), 112-115.

Kimkong, H., \& Koemhong, S. (2020). Online Learning during COVID-19: Key Challenges and Suggestions to Enhance Effectiveness. Cambodian Education Forum (CEF), December, 1-15. https://www.researchgate.net/publication/346719308_Online_learning_during_ COVID-19_Key_challenges_and_suggestions_to_enhance_effectiveness 
Martinez, J. E. (2017). The Search for Method in STEAM Education. In Palgrave Macmillan. Springer Nature. https://doi.org/10.1007/978-3-319-55822-6

Mcclure, E. R., Guernsey, L., Clements, D. H., Bales, S. N., Nichols, J., Kendall-Taylor, N., \& Levine, M. H. (2017). STEM starts early: Grounding science, technology, engineering, and math education in early childhood. http://joanganzcooneycenter.org/publication/stem-starts-early/

Michaud, M. R. (2014). STEAM: Adding Art to STEM education. District Administration, 50(1).

Munawar, M., Roshayanti, F., \& Sugiyanti, S. (2019). Implementation of STEAM (Science Technology Engineering Art Mathematics)-based Early Childhood Education Learning in Semarang City. CERIA (Cerdas Energik Responsif Inovatif Adaptif), 2(5), 276. https://doi.org/10.22460/ceria.v2i5.p276-285

Perignat, E., \& Katz-Buonincontro, J. (2019). STEAM in practice and research: An integrative literature review. Thinking Skills and Creativity, 31, 31-43. https://doi.org/10.1016/j.tsc.2018.10.002

Pfeiffer, D. H., Ignatov, D. I., Poelmans, J., \& Gadiraju, N. (2013). Conceptual Structures for STEM Research and Education. 20th International Conference on Conceptual Structures.

Quigley, C. ., \& Herro, D. (2016). Implementation of STEAM Teaching Practices in Middle School Science and Math Classrooms. Journal of Science Education and Technology. https://doi.org/10.1007/s10956-016-9602-z

Sochacka, N. W., Guyotte, K. W., \& Walther, J. (2016). Learning Together: A Collaborative Autoethnographic Exploration of STEAM. Journal of Engineering Education, 105(1). https://doi.org/doi:10.1002/jee.20112

Taguma, M., Litjens, I., \& Makowiecki, K. (2012). Quality Matters in Early Childhood Education and Care: Czech Republic. In OECD. https://doi.org/10.1007/978-1137-29380-0_20

Thuneberg, H. ., Salmi, H. ., \& Bogner, F. X. (2018). How Creativity, Autonomy and Visual Reasoning Contribute to Cognitive Learning in A STEAM Hands-on Inquiry-based Math Module. Thinking Skills and Creativity. https://doi.org/10.1016/j.tsc.2018.07.003 
Torlakson, T. (2014). INNOVATE: A Blueprint for Science, Technology, Engineering, and Mathematics in California Public Education. California. California Departement Of Education.

Wahyuningsih, S., Nurjanah, N. E., Rasmani, U. E. E., Hafidah, R., Pudyaningtyas, A. ., \& Syamsuddin, M. . (2020). STEAM Learning in Early Childhood Education: A Literature Review. International Journal of Pedagogy and Teacher Education (IJPTE), 4(1), 33-44.

Yalcin, M. (2015). Progressive Development of Creative Design Skills from Kindergarden Education. Form Akademisk - Forskningstidsskrift for Design Og Designdidaktikk. https://doi.org/10.7577/formakademisk.1403

Yennizar, Zulqarnain, Eriyani, E., Zukhairina, Susanti, N., \& Kausari, D. (2020). Application Of Lesson Study with A Scientific Approach : A Case Study Of Early Childhood Education. Journal of Critical Reviews, 7(7), 104-111. 